\title{
PROBABILITAS BANGKITAN PERJALANAN BERBASIS AKTIVITAS DARI KAWASAN PERUMAHAN DI KOTA KUPANG
}

\author{
Oktovianus Edvict Semiunn ${ }^{1)}$, Egidius Kalogo ${ }^{2)}$ \\ Program Studi Teknik Sipil, Fakultas Teknik, Universitas Katolik Widya Mandira \\ email: oktovianussemiun@unwira.ac.id ${ }^{1)}$,egidiuskalogo@yahoo.com $^{2)}$
}

DOI: http://dx.doi.org/10.29103/tj.v10i2.292

(Received: July 2020 / Revised: August 2020 / Accepted: August 2020)

\begin{abstract}
Abstrak
Bangkitan perjalanan umumnya dilakukan berdasarkan aktivitas dari suatu rumah tangga. Setiap anggota rumah tangga tentu saja memiliki tujuan perjalanan yang berbeda-beda sehingga pada suatu rumah tangga terjadi beberapa perjalanan yang disebabkan oleh adanya aktivitas. Penelitian ini bertujuan untuk menentukan faktorfaktor yang mempengaruhi bangkitan perjalanan dan memprediksi besarnya bangkitan perjalanan yang berasal dari Kawasan Perumahan berdasarkan aktivitas di Kota Kupang. Bangkitan perjalanan dibagi menjadi tiga kategori yaitu aktivitas bekerja, aktivitas sekolah dan aktivitaslainnya. Pengumpulan data dilakukan dengan menyebarkan kuesioner kepada 444 rumah tangga melalui teknik random sampling. Berdasarkan kalibrasi hasil pemodelan dengan analisis regresi multinomial logit, faktor-faktor yang secara signifikan mempengaruhi bangkitan perjalanan dari Kawasan Perumahan adalah jumlah anggota keluarga yang melakukan aktivitas, jarak rata-rata yang ditempuh dan waktu perjalanan rata-rata. Probabilitas bangkitan perjalanan diperkirakan 55,48\% untuk aktivitas bekerja, 25,61\% untuk aktivitas sekolah dan $18,90 \%$ untuk aktivitas lainnya.
\end{abstract}

Kata kunci: Multinomial logit, probabilitas, aktivitas perjalanan, bangkitan perjalanan

\begin{abstract}
Generally, trip generation is based on activities from the household. Each household member, of course, has different travel destinations in a household, there will be several trips that are caused by the activity. This study is aimed at determining the factors that influence the trip generation and predict the magnitude of trip generation originating from residential areas based on activities in Kupang city. Travel activities were divided into three categories i.e. work activities, school activities and other activities. Data collection was done by distributing questionnaires to 444 households through random sampling technique. Based on the calibration of the modelling results with multinomial logit regression analysis, the factors that significantly influence trip generation from residential areas were the number of family members who did activities, the average distance travelled and the average travel time. The probability of trip generation was predicted to be $55.48 \%$ for work activities, $25.61 \%$ for school activities and $18.90 \%$ for other activities.
\end{abstract}

Keywords: multinomial logit, probability, trip activities, trip generation

Probabilitas Bangkitan Perjalanan Berbasis Aktivitas Dari Kawasan Perumahan di Kota Kupang - Oktovianus Edvict Semiun, Egidius Kalogo 


\section{Latar Belakang}

Pertumbuhan penduduk yang cenderung meningkat di Kota Kupang berdampak pada perubahan tata guna lahan di mana luas kawasan perumahan semakin besar. Selain itu, peningkatan jumlah penduduk juga berpengaruh terhadap peningkatan jumlah kendaraan pribadi di Kota Kupang. Peningkatan kepemilikkan kendaraan pribadi di Kota Kupang dipengaruhi oleh jumlah anggota keluarga, penghasilan, jumlah anggota keluarga yang bekerja, jumlah anggota keluarga yang sekolah dan waktu tempuh ke sekolah (Semiun, 2019). Selain itu, faktor yang mempengaruhi peningkatan kepemilikkan kendaraan pribadi juga disebabkan oleh fasilitas angkutan umum yang belum optimal (Asadi et al., 2016). Hal ini didukung oleh hasil penelitian terdahulu yang menyatakan bahwa kondisi kualitas angkutan umum di Kota Kupang saat ini belum sesuai dengan standar pelayanan yang diinginkan (Semiun, 2015). Kinerja angkutan umum di Kota Kupang yang diharapkan masih dibawah indeks kepuasan penumpang (Semiun, 2015, 2018). Di sisi lain, walaupun kendaraan pribadi memudahkan individu untuk melakukan aktivitas kesehariannya namun hal tersebut justru berdampak pada menurunnya kinerja ruas jalan di Kota Kupang. Kondisi ini disebabkan oleh volume arus lalulintas yang bertambah sehingga dapat menimbulkan kemacetan. Kemacetan menambah waktu normal perjalanan untuk sampai ke tempat tujuan. Akibatnya, proses aktivitas masyarakat menjadi terhambat, contohnya dalam kehidupan sosial, ekonomi, pendidikan dan lain sebagainya. Kemacetan lalulintas dapat menyebabkan pemborosan waktu, biaya, meningkatkan polusi dan menyebabkan stres serta menurunkan produktivitas masyarakat (Mohan Rao \& Ramachandra Rao, 2012) Keseluruhan interaksi ini sangat berpengaruh terhadap bangkitan perjalanan yang terjadi di Kota Kupang.

Dalam pemodelan perencanaan transportasi perkotaan, model berbasis perjalanan telah berkembang selama beberapa dekade (Castiglione et al., 2014). Seperti namanya, model berbasis perjalanan menggunakan perjalanan orang secara individu sebagai unit dasar analisis. Model berbasis perjalanan digunakan secara luas dalam praktiknya untuk mendukung analisis transportasi dan pengambilan keputusan di tingkat regional, subregional, dan tingkat proyek. Model berbasis perjalanan sering disebut sebagai model "4-tahap" karena mencakup empat komponen utama yaitu trip generation, trip distribution, mode choice analysis dan traffic assignment (Goel et al., 2012; Sai Simha Gorji, 2017).

Bangkitan perjalanan (trip generation) bertujuan untuk memprediksi jumlah total perjalanan yang dibangkitkan dan ditarik ke tiap zona (Parikh \& Varia, 2016; Patel \& Patel, 2015). Bangkitan perjalanan menyatakan estimasi jumlah perjalanan baru yang dibangkitkan, baik yg diciptakan maupun ditarik oleh suatu kawasan baru. Lebih lanjut dijelaskan bahwa setiap perjalanan yang dibangkitkan oleh suatu kawasan baru dapat diestimasi melalui proses tersebut (Al-Sahili et al., 2018). Pada umumnya, bangkitan perjalanan dipengaruhi oleh sejumlah faktor seperti: karakteristik sosio-ekonomi trip-maker, karakteristik penggunaan lahan, perkembangan suatu kawasan, jarak dari Kota atau pusat kota (Sai Simha Gorji, 2017). Pada level individual, transportasi perkotaan dapat ditandai oleh perjalanan individu yang secara umum diklasifikasikan berdasarkan tujuan utama misalnya perjalanan kerja, belanja, perjalanan sosial, rekreasi, sekolah, rumah maupun bisnis (Patel Bhargavibahen Vinodbhai et al., 2017). 
Pendekatan berbasis aktivitas adalah alat praktis yang mengatasi masalah dalam metode tradisional seperti pendekatan berbasis perjalanan. Analisis permintaan perjalanan berdasarkan aktivitas memandang perjalanan sebagai permintaan turunan yang berasal dari kebutuhan untuk melakukan aktivitas yang didistribusikan dalam ruang. Pendekatan ini mengadopsi kerangka kerja holistik yang menguatkan adanya interaksi yang kompleks antara aktivitas dan perilaku perjalanan (Hedau \& Sanghai, 2014). Analisis bangkitan perjalanan berbasis aktivitas telah berkembang dari penelitian tentang perilaku perjalanan individu ke perilaku perjalanan rumah tangga karena banyak peneliti telah menyadari bahwa individu tidak dapat membuat keputusan secara terpisah. Sebaliknya mereka bertanggungjawab untuk urusan rumah tangga dan selalu berinteraksi satu sama lain dalam rumah tangga yang sama pada kegiatan atau partisipasi perjalanan, seperti kegiatan pemeliharaan rumah tangga, penjemputan/pengantaran anggota keluarga, waktu luang dan kegiatan rekreasi (Yang et al., 2016).

Aktivitas perjalanan dikelompokkan ke dalam empat kategori umum berdasarkan prioritas dalam jadwal pola aktivitas harian. Kategori aktivitas tersebut adalah mandatory, maintenance, discretionary dan dalam rumah. Aktivitas mandatory terdiri dari bekerja dan sekolah/kuliah. Aktivitas maintenance contohnya mengantar/menemani, belanja, dan pemeliharaan lainnya (misalnya kunjungan dokter). Aktivitas seperti rekreasi, kunjungan sosial dan aktivitas senang-senang lainnya dikategorikan sebagai aktivitas discretionary. Sedangkan contoh aktivitas dalam rumah seperti bekerja di rumah dan aktivitas di rumah yang bukan kerja (Castiglione et al., 2014). Dalam membuat suatu model berdasarkan tujuan perjalanan, aktivitas maintenance dan discretionary dapat digabungkan menjadi aktivitas nonmandatory yaitu aktivitas seperti belanja harian, belanja yang tidak dilakukan perhari, membawa dan mengantar anak atau orang lain serta aktivitas lainnya seperti rekreasi, kunjungan sosial dan aktivitas hiburan lainnya (Anggraini, 2009). Berdasarkan jenis aktivitas tersebut, maka bangkitan perjalanan dipengaruhi oleh pemilihan lokasi tujuan aktivitas yang dilakukan oleh anggota rumah tangga. Pemilihan lokasi ini berkaitan dengan perjalanan yang dilakukan oleh individu menuju ke Kantor, ke Sekolah/Kampus maupun ke tempat lainnya seperti pusat perbelanjaan, tempat aktivitas sosial, tempat rekreasi, dan lain sebagainya.

Tujuan penelitian ini adalah untuk menentukan faktor-faktor yang mempengaruhi bangkitan perjalanan serta memprediksi besarnya bangkitan perjalanan yang berasal dari kawasan perumahan berdasarkan aktivitas pelaku perjalanan di Kota Kupang.

\section{Metode Penelitian}

Penelitian ini dianalisis menggunakan regresi mutinomial logit. Model multinomial logit (MNL) adalah salah satu model pilihan paling populer dan digunakan untuk menganalisis pilihan individu ketika variabel dependen adalah variabel multi kriteria diskrit yang berkaitan dengan sejumlah variabel independen. Dalam pemodelan bangkitan perjalanan menggunakan model MNL, diasumsikan bahwa probabilitas rumah tangga yang melakukan sejumlah aktivitas perjalanan adalah fungsi dari sejumlah variabel independen ( $\mathrm{Hu}, 2010)$. Fungsi logit merupakan bagian penting dari suatu pilihan diskrit dan regresi logistik. Regresi logistik memprediksi kemungkinan terjadinya suatu peristiwa tertentu 
berdasarkan variabel independen. Model pilihan diskrit adalah fungsi matematika yang memprediksi pilihan individu berdasarkan utilitas. Oleh karena itu, penggunaan model multinomial logit dengan metode pilihan diskrit adalah metode pemodelan analitik yang mudah (Miskeen et al., 2013). Model MNL adalah salah satu model yang paling sederhana dalam kerangka model logit, dimana diasumsikan bahwa komponen didistribusikan acak secara independen dan identik (Sreerag et al., 2016).

Dalam penelitian ini, aktivitas perjalanan dikelompokkan menjadi aktivitas mandatory dan nonmandatory. Aktivitas mandatory dikategorikan sebagai aktivitas bekerja dan sekolah/kuliah. Sedangkan aktivitas nonmandatory merupakan gabungan dari aktivitas maintenance, discretionary dan dalam rumah yang dikategorikan sebagai aktivitas lainnya. Sebagai kategori dasar adalah aktivitas lainnya. Variabel dependen merupakan data kategori sedangkan variabel independen adalah data covariance. Selengkapnya dapat dilihat pada Tabel 1.

Tabel 1 Variabel Penelitian

\begin{tabular}{|c|c|c|}
\hline Variabel Dependen & Kategori & Kode \\
\hline \multirow{3}{*}{ Y Aktivitas Perjalanan } & Aktivitas Lainnya & 0 \\
\hline & Aktivitas Bekerja & 1 \\
\hline & Aktivitas Sekolah & 2 \\
\hline Variabel Independen & Covariance & Kode \\
\hline \multirow{4}{*}{ X1 Jumlah Anggota Keluarga } & 1 - 2 Orang & 1 \\
\hline & 3-4 Orang & 2 \\
\hline & 5 - 6 Orang & 3 \\
\hline & $>6$ Orang & 4 \\
\hline \multirow{5}{*}{ X2 Penghasilan Perbulan } & $<1.5$ Juta Rp. & 1 \\
\hline & 1.5 - 3 Juta Rp. & 2 \\
\hline & 3 - 4.5 Juta Rp. & 3 \\
\hline & 4.5 - 6 Juta Rp. & 4 \\
\hline & > 6 Juta Rp. & 5 \\
\hline \multirow{4}{*}{ X3 Jenis Pekerjaan } & PNS/BUMN & 1 \\
\hline & Pegawai Swasta & 2 \\
\hline & Wiraswasta & 3 \\
\hline & Lainnya & 4 \\
\hline \multirow{3}{*}{ X4 Jumlah Kendaraan Pribadi } & Tidak Ada & 1 \\
\hline & 1 - 2 Unit & 2 \\
\hline & $>2$ Unit & 3 \\
\hline \multirow{3}{*}{$\begin{array}{c}\text { X5 Jumlah Anggota Keluarga } \\
\text { yang Beraktivitas }\end{array}$} & 1 Orang & 1 \\
\hline & 2 - 3 Orang & 2 \\
\hline & $>3$ Orang & 3 \\
\hline \multirow{4}{*}{$\begin{array}{l}\text { X6 Jenis Kendaraan yang } \\
\text { Digunakan Saat Beraktivitas }\end{array}$} & Kendaraan Pribadi & 1 \\
\hline & Kendaraan Jemputan & 2 \\
\hline & Angkutan Umum & 3 \\
\hline & Lainnya & 4 \\
\hline \multirow{4}{*}{$\begin{array}{c}\text { X7 Jarak Tempuh Rata-rata Saat } \\
\text { Beraktivitas }\end{array}$} & $<5 \mathrm{Km}$ & 1 \\
\hline & $5-15 \mathrm{Km}$ & 2 \\
\hline & $16-25 \mathrm{Km}$ & 3 \\
\hline & $>25 \mathrm{Km}$ & 4 \\
\hline \multirow{4}{*}{$\begin{array}{c}\text { X8 Waktu Tempuh Rata-rata Saat } \\
\text { Beraktivitas }\end{array}$} & $<10$ Menit 1 & 1 \\
\hline & $11-20$ Menit & 2 \\
\hline & $21-30$ Menit & 3 \\
\hline & > 30 Menit & 4 \\
\hline
\end{tabular}


Kuisioner penelitian disebarkan secara acak kepada responden di Kota Kupang sebanyak 444 rumah tangga berdasarkan perhitungan ukuran populasi 97725 rumah tangga (Badan Pusat Statistik Kota Kupang, 2019) dengan rumus Slovin pada taraf signifikan 5\%. Pengumpulan data dilakukan selama dua bulan yaitu dari bulan Februari sampai bulan Maret tahun 2020.

Model statis bangkitan perjalanan dalam penelitian ini merupakan model kalibrasi MNL menggunakan bantuan Software SPSS 16. Sebelum dilakukan kalibrasi pemodelan, terlebih dahulu dilakukan pengujian validitas dan reliabilitas data kuisioner agar data yang digunakan valid dan akurat. Langkah-langkah dalam kalibrasi model MNL terdiri dari uji validitas dan reliabilitas kuisioner, uji asumsi klasik, uji kesesuaian model, uji signifikansi variabel independen secara serentak (Overall Model Fit), uji signifikansi variabel independen secara individual (Significance Test), estimasi parameter dan validasi model. Setelah model MNL bangkitan perjalanan dinyatakan valid dan akurat kemudian dilakukan interpretasi secara individual terhadap probabilitas bangkitan perjalanan yang terjadi berbasis nilai $O d d s$ dan simulasi peluang. Besarnya probabilitas bangkitan perjalanan ditentukan berdasarkan frekuensi nilai rata-rata dari faktor-faktor yang berpengaruh signifikan terhadap aktivitas perjalanan.

\section{Hasil dan Pembahasan}

\subsection{Model Bangkitan Perjalanan Berdasarkan Aktivitas}

3.1.1 Uji Validitas dan Reliabilitas

Pengujian validitas menggunakan korelasi Person Product Moment dengan kriteria validitas $r$ hitung lebih besar dari $r$ tabel pada derajat signifikan 5\% dan taraf df (degree of freedom) n-2 yaitu 442, diperoleh nilai $\mathrm{r}$ tabel 0.094 . Berdasarkan Tabel 2 dapat diketahui bahwa setiap variabel mempunyai nilai $r$ hitung yang lebih besar dari $r$ tabel. Hal ini berarti variabel independen dalam penelitian ini layak atau valid.

Uji realibilias dilakukan setelah uji validitas pada variabel dinyatakan valid. Uji reliabilitas menggunakan metode Cronbach Alpha. Jika alpha > 0.90 maka reliabilitas sempurna. Jika alpha antara $0.70-0.90$ maka reliabilitas tinggi. Jika alpha $0.50-0.70$ maka reliabilitas moderat. Jika alpha $<0.50$ maka reliabilitas rendah. Jika alpha rendah, berarti item tidak reliabel. Berdasarkan Tabel 2, nilai Cronbach Alpha menunjukan nilai diatas 0.50 sehingga variabel independen dalam penelitian ini reliabel.

Tabel 2 Hasil uji validitas dan reliabilitas

\begin{tabular}{cccccccc}
\hline \multicolumn{4}{c}{ Uji Validitas } & \multicolumn{5}{c}{ Uji Reliabilitas } \\
\hline Variabel & r hitung & r tabel & Ket. & Variabel & Cronbach Alpha & Syarat & Ket. \\
\hline X1 & 0.515 & 0.094 & Valid & X1 & 0.606 & 0.50 & Reliabel \\
\hline X2 & 0.525 & 0.094 & Valid & X2 & 0.603 & 0.50 & Reliabel \\
\hline X3 & 0.121 & 0.094 & Valid & X3 & 0.694 & 0.50 & Reliabel \\
\hline X4 & 0.441 & 0.094 & Valid & X4 & 0.621 & 0.50 & Reliabel \\
\hline X5 & 0.403 & 0.094 & Valid & X5 & 0.625 & 0.50 & Reliabel \\
\hline X6 & 0.153 & 0.094 & Valid & X6 & 0.656 & 0.50 & Reliabel \\
\hline X7 & 0.642 & 0.094 & Valid & X7 & 0.578 & 0.50 & Reliabel \\
\hline X8 & 0.613 & 0.094 & Valid & X8 & 0.585 & 0.50 & Reliabel \\
\hline
\end{tabular}




\subsubsection{Uji Asumsi Klasik}

Tabel 3 menunjukkan hasil uji multikolinearitas. Nilai Tolerance untuk semua variabel independen mendekati 1 dan nilai VIF kurang dari 10 sehingga diduga tidak terjadi multikolinearitas.

Tabel 3 Uji multikolinearitas

\begin{tabular}{llcc}
\hline \multicolumn{1}{c}{ Model } & \multicolumn{2}{c}{ Collinearity } & Statistics \\
\cline { 2 - 3 } & Tolerance & VIF \\
\hline 1 & .764 & 1.309 \\
\cline { 2 - 3 } Jumlah Anggota Keluarga (X1) & .660 & 1.516 \\
\cline { 2 - 4 } Penghasilan Perbulan (X2) & .869 & 1.150 \\
\cline { 2 - 3 } & Jenis Pekerjaan (X3) & .643 & 1.556 \\
\cline { 2 - 4 } Jumlah Kendaraan Pribadi (X4) & .939 & 1.065 \\
\hline Jumlah Anggota Keluarga yang Beraktivitas (X5) & .924 & 1.082 \\
\hline Jenis Kendaraan yang digunakan Saat Beraktivitas (X6) & .505 & 1.979 \\
\hline Jarak Tempuh Rata-rata Saat Beraktivitas (X7) & .512 & 1.953 \\
\hline Waktu Tempuh Rata-rata Saat Beraktivitas (X8) &
\end{tabular}

\subsubsection{Uji Kesesuaian Model}

Pada Tabel 4, nilai Sig. Pearson 0.213 dan nilai Sig. Deviance 0.435 artinya model fit atau model MNL dalam penelitian ini layak untuk digunakan karena nilainya lebih besar dari 0.05 . Selain itu ukuran kebaikan regresi logistik disebut juga $P$ seudo $R^{2}$ yang ditunjukkan pada Tabel 4 . Dari tabel tersebut diperoleh nilai Cox dan Snell $R^{2}$ sebesar 0.310 , nilai Nagelkerke $R^{2}$ sebesar 0.348 dan nilai McFadden $R^{2}$ sebesar 0.169. Nilai ini merupakan pendekatan awal karena pada regresi logistik yang perlu diperhatikan adalah seberapa banyak data yang diprediksi dengan benar yang tercermin dari nilai Classification Plot.

Tabel 4 Goodness of fit dan pseudo r-square

\begin{tabular}{|c|c|c|c|}
\hline \multicolumn{4}{|c|}{ Goodness of Fit } \\
\hline & Chi-Square & df & Sig. \\
\hline Pearson & 545.380 & 520 & .213 \\
\hline Deviance & 524.618 & 520 & .435 \\
\hline \multicolumn{4}{|c|}{ Pseudo R-Square } \\
\hline \multicolumn{2}{|c|}{ Cox dan Snell } & \multicolumn{2}{|c|}{.310} \\
\hline \multicolumn{2}{|c|}{ Nagelkerke } & \multicolumn{2}{|c|}{.348} \\
\hline \multicolumn{2}{|c|}{ McFadden } & \multicolumn{2}{|c|}{.169} \\
\hline
\end{tabular}

\subsubsection{Uji Signifikansi Variabel Independen Secara Serentak (Overall Model Fit)}

Dari Tabel 5 diperoleh nilai Chi-Square hitung sebesar 164.431. Dengan derajat bebas atau degree of freedom (df) sebesar 16 dan tingkat kepercayaan $(\alpha)$ 0.05, diperoleh nilai Chi-Square tabel sebesar 26.30 (Chi-Square hitung > ChiSquare tabel) sehingga disimpulkan bahwa semua variabel independen secara bersama-sama mempengaruhi variabel dependen. 
Tabel 5 Overall model fit

\begin{tabular}{lccc}
\hline \multirow{2}{*}{ Model } & \multicolumn{3}{c}{ Likelihood Ratio Test } \\
\cline { 2 - 4 } & Chi-Square & df & Sig. \\
\hline $\begin{array}{l}\text { Intercept Only } \\
\text { Final }\end{array}$ & 164.431 & 16 & .000 \\
\hline
\end{tabular}

\subsubsection{Uji Signifikansi Variabel Independen Secara Individual (Significance Test)}

Berdasarkan Tabel 6 dengan nilai df sebesar 2 dan tingkat kepercayaan $(\alpha)$ 0.05 diperoleh nilai Chi-Square tabel sebesar 5.99. Syarat: Chi-Square hitung > Chi-Square tabel sehingga variabel independen yang mempengaruhi variabel dependen adalah X5 (jumlah anggota keluarga yang beraktivitas), X7 (jarak tempuh rata-rata saat beraktivitas) dan $\mathrm{X} 8$ (waktu tempuh rata-rata saat beraktivitas).

Tabel 6 Likelihood ratio test

\begin{tabular}{lcccc}
\hline \multicolumn{1}{c}{ Effect } & Chi-Square hitung & df & Sig. & Chi-Square tabel \\
\hline Intercept & 19.348 & 2 & .000 & 5.99 \\
\hline X1 & 1.507 & 2 & .471 & 5.99 \\
\hline X2 & 0.276 & 2 & .871 & 5.99 \\
\hline X3 & 1.416 & 2 & .493 & 5.99 \\
\hline X4 & 0.105 & 2 & .949 & 5.99 \\
\hline X5 & 128.870 & 2 & .000 & 5.99 \\
\hline X6 & 4.706 & 2 & .095 & 5.99 \\
\hline X7 & 19.286 & 2 & .000 & 5.99 \\
\hline X8 & 27.052 & 2 & .000 & 5.99 \\
\hline
\end{tabular}

\subsubsection{Estimasi Parameter}

Estimasi parameter dilakukan untuk mendapatkan nilai konstanta dan koefisien pada model. Pada Tabel 7 ditunjukkan hasil estimasi parameter yang diperoleh dari output SPSS. Pada penelitian ini, variabel dependen adalah aktivitas perjalanan dari kawasan perumahan. Sebagai kategori dasar adalah aktivitas lainnya, $\mathrm{Y}_{0}=0$. Fungsi logit dari bangkitan perjalanan berbasis aktivitas secara keseluruhan adalah sebagai berikut:

$$
\begin{aligned}
& Y_{0}=0 \\
& Y_{1}=-4.019+2.962\left(X_{5}\right)-0.879\left(X_{7}\right)+1.215\left(X_{8}\right) \\
& Y_{2}=-3.500+2.492\left(X_{5}\right)-1.009\left(X_{7}\right)+1.034\left(X_{8}\right)
\end{aligned}
$$

Sehingga diperoleh model regresi multinomial logit bangkitan perjalanan adalah sebagai berikut:

$$
\begin{aligned}
& \text { AktivitasLainnya }=P_{0} \frac{e^{Y 0}}{e^{Y 0}+e^{Y 1}+e^{Y 2}} \\
& \text { AktivitasBekerja }=P_{1} \frac{e^{Y 1}}{e^{Y 0}+e^{Y 1}+e^{Y 2}}
\end{aligned}
$$




$$
\text { AktivitasSekolah }=P_{2} \frac{e^{Y 2}}{e^{Y 0}+e^{Y 1}+e^{Y 2}}
$$

Tabel 7 Estimasi parameter model bangkitan perjalanan

\begin{tabular}{|c|c|c|c|c|c|c|c|c|}
\hline \multirow[b]{2}{*}{$\begin{array}{c}\text { Aktivitas } \\
\text { Perjalanan }^{a}\end{array}$} & \multirow[b]{2}{*}{$\boldsymbol{B}$} & \multirow[b]{2}{*}{$S E$} & \multirow[b]{2}{*}{ Wald } & \multirow[b]{2}{*}{$d f$} & \multirow[b]{2}{*}{ Sig. } & \multirow[b]{2}{*}{$\operatorname{Exp}(B)$} & \multicolumn{2}{|c|}{$95 \%$ CI for $\operatorname{Exp}(B)$} \\
\hline & & & & & & & $\begin{array}{l}\text { Lower } \\
\text { Bound }\end{array}$ & $\begin{array}{c}\text { Upper } \\
\text { Bound }\end{array}$ \\
\hline \multicolumn{9}{|l|}{ Aktivitas Bekerja } \\
\hline Intercept & -4.019 & 1.011 & 15.792 & 1 & .000 & & & \\
\hline $\mathrm{X} 1$ & -.270 & .228 & 1.412 & 1 & .235 & .763 & .488 & 1.192 \\
\hline $\mathrm{X} 2$ & -.096 & .208 & .211 & 1 & .646 & .909 & .605 & 1.366 \\
\hline $\mathrm{X} 3$ & .170 & .143 & 1.416 & 1 & .234 & 1.185 & .896 & 1.568 \\
\hline $\mathrm{X} 4$ & -.070 & .352 & .040 & 1 & .842 & .932 & .468 & 1.858 \\
\hline $\mathrm{X} 5$ & 2.962 & .326 & 82.536 & 1 & .000 & 19.340 & 10.208 & 36.644 \\
\hline X6 & .011 & .271 & .002 & 1 & .968 & 1.011 & .595 & 1.719 \\
\hline $\mathrm{X} 7$ & -.879 & .261 & 11.334 & 1 & .001 & .415 & .249 & .693 \\
\hline $\mathrm{X} 8$ & 1.215 & .267 & 20.655 & 1 & .000 & 3.372 & 1.996 & 5.695 \\
\hline \multicolumn{9}{|c|}{ Aktivitas Sekolah/Kuliah } \\
\hline Intercept & -3.500 & .962 & 13.235 & 1 & .000 & & & \\
\hline $\mathrm{X} 1$ & -.210 & .216 & .943 & 1 & .331 & .811 & .531 & 1.238 \\
\hline $\mathrm{X} 2$ & -.017 & .199 & .008 & 1 & .931 & .983 & .666 & 1.451 \\
\hline $\mathrm{X} 3$ & .091 & .139 & .433 & 1 & .511 & 1.095 & .835 & 1.437 \\
\hline $\mathrm{X} 4$ & .021 & .336 & .004 & 1 & .950 & 1.021 & .529 & 1.972 \\
\hline$\times 5$ & 2.492 & .319 & 61.103 & 1 & .000 & 12.089 & 6.471 & 22.583 \\
\hline X6 & .391 & .242 & 2.616 & 1 & .106 & 1.479 & .921 & 2.376 \\
\hline $\mathrm{X} 7$ & -1.009 & .253 & 15.932 & 1 & .000 & .365 & .222 & .598 \\
\hline X8 & 1.034 & .256 & 16.336 & 1 & .000 & 2.812 & 1.703 & 4.642 \\
\hline
\end{tabular}

a. The Reference Category is Aktivitas Lainnya

\subsubsection{Validasi Model}

Validasi dari probabilitas yang diprediksi dapat dilihat pada Tabel 8. Percent Correct menunjukkan seberapa besar model MNL memprediksi data yang diobservasi dengan benar sedangkan Overall Percentage menunjukkan persentase ketepatan prediksi aktivitas perjalanan secara menyeluruh. Tabel 9 memberikan nilai overall percentage sebesar $56.3 \%$ yang berarti ketepatan model penelitian ini adalah sebesar $56.3 \%$. Keseluruhan data yang diprediksi dengan benar oleh model MNL berada diatas $50 \%$ sehingga model MNL ini dinyatakan valid.

Tabel 8 Hasil validasi model

\begin{tabular}{ccccc}
\hline \multirow{2}{*}{ Observed } & \multicolumn{5}{c}{ Predicted } \\
\cline { 2 - 5 } & Lainnya & Bekerja & Sekolah & Percent Correct \\
\hline Lainnya & 121 & 9 & 19 & $81.8 \%$ \\
\hline Bekerja & 26 & 88 & 34 & $59.5 \%$ \\
\hline Sekolah & 46 & 61 & 41 & $27.7 \%$ \\
\hline Overall Percentage & $43.5 \%$ & $35.4 \%$ & $21.2 \%$ & $56.3 \%$ \\
\hline
\end{tabular}

\subsection{Interpretasi Probabilitas Bangkitan Perjalanan Berbasis Aktivitas}

\subsubsection{Interpretasi Nilai Odds}

Berdasarkan hasil analisis, diketahui bahwa hasil analisis model MNL untuk variabel jumlah anggota keluarga yang beraktivitas, jarak tempuh rata-rata dan waktu tempuh rata-rata berpengaruh nyata (dalam taraf nyata 5\%) terhadap probabilitas bangkitan perjalanan berdasarkan aktivitas dari kawasan perumahan 
di Kota Kupang. Interpretasi berbasis nilai Odds pada Tabel 7 dapat dijelaskan sebagai berikut:

* Setiap penambahan satu satuan jumlah anggota keluarga yang beraktivitas meningkatkan odds aktivitas bekerja terhadap aktivitas lainnya sebesar $\exp (\mathrm{X} 5)=19.34$ kali dan meningkatkan odds aktivitas sekolah terhadap aktivitas lainnya sebesar $\exp (X 5)=12.089$ kali.

* Karena X7 bernilai negative maka interpretasinya dapat dibalik yaitu setiap penambahan satu satuan jarak tempuh rata-rata meningkatkan odds aktivitas lainnya terhadap aktivitas bekerja sebesar $\exp (-\mathrm{X} 7)=1.514$ kali dan meningkatkan odds aktivitas lainnya terhadap aktivitas sekolah sebesar exp($\mathrm{X} 7)=1.441$ kali.

* Setiap penambahan satu satuan waktu tempuh rata-rata meningkatkan odds aktivitas bekerja terhadap aktivitas lainnya sebesar $\exp (\mathrm{X} 8)=3.372$ kali dan meningkatkan odds aktivitas sekolah terhadap aktivitas lainnya sebesar $\exp (\mathrm{X} 8)=2.812$ kali.

Hasil pengujian menunjukkan bahwa faktor jumlah anggota keluarga yang beraktivitas, jarak tempuh rata-rata dan waktu tempuh rata-rata terbukti berpengaruh terhadap bangkitan perjalanan. Semakin banyak jumlah anggota keluarga yang beraktivitas, semakin besar kecenderungan probabilitas terjadinya bangkitan perjalanan berdasarkan aktivitas mandatory (bekerja dan sekolah) dibandingkan dengan aktivitas nonmandatory (aktivitas lainnya). Semakin panjang jarak tempuh rata-rata, semakin kecil kecenderungan probabilitas terjadinya bangkitan perjalanan berdasarkan aktivitas mandatory (bekerja dan sekolah) dibandingkan dengan aktivitas nonmandatory (aktivitas lainnya). Semakin lama waktu tempuh rata-rata, semakin besar kecenderungan probabilitas terjadinya bangkitan perjalanan berdasarkan aktivitas mandatory (bekerja dan sekolah) dibandingkan aktivitas nonmandatory (aktivitas lainnya).

\subsubsection{Interpretasi Berbasis Peluang}

Interpretasi berbasis peluang dilakukan dengan mensubstitusikan persamaan fungsi logit aktivitas perjalanan (1), (2) dan (3) ke dalam persamaan model MNL (4), (5) dan (6). Kemudian dibuat simulasi probabilitas secara individual dari setiap faktor yang berpengaruh nyata terhadap bangkitan perjalanan. Simulasi dilakukan dengan meningkatkan nilai faktor tersebut dari nilai minimum ke maksimum kemudian dilihat kecendrungan hasil probabilitasnya untuk aktivitas bekerja, aktivitas sekolah/kuliah dan aktivitas lainnya.

\section{a. Simulasi 1: Pengaruh jumlah anggota keluarga yang beraktivitas terhadap probabilitas bangkitan perjalanan.}

Berdasarkan Tabel 9 dan Gambar 1, jika faktor jumlah anggota keluarga yang beraktivitas bergerak dari nilai minimum ke maksimum mengakibatkan probabilitas aktivitas bekerja dan sekolah cenderung meningkat. Untuk aktivitas bekerja, probabilitasnya mulai dari $1.71 \%$ menjadi $70.51 \%$ dan untuk aktivitas sekolah probabilitasnya mulai dari $2.88 \%$ menjadi $28.95 \%$. Sedangkan untuk aktivitas lainnya, penambahan jumlah anggota keluarga yang beraktivitas cenderung menurunkan probabilitasnya yaitu mulai dari $95.40 \%$ menjadi $0.54 \%$. 
Perubahan ekstrim jumlah anggota keluarga yang beraktivitas (nilai berubah dari 0 ke 3) meningkatkan probabilitas bangkitan perjalanan untuk aktivitas bekerja sebesar $68.79 \%$ (dari $1.71 \%$ menjadi $70.51 \%$ ), meningkatkan probabilitas bangkitan perjalanan untuk aktivitas sekolah sebesar $26.07 \%$ (dari $2.88 \%$ menjadi $28.95 \%$ ) dan menurunkan probabilitas bangkitan perjalanan untuk aktivitas lainnya sebesar $94.86 \%$ (dari $95.40 \%$ menjadi $0.54 \%$ ). Berdasarkan hasil analisis, diketahui bahwa perubahan dugaan peluang sebagai akibat penambahan jumlah anggota keluarga yang beraktivitas pada aktivitas bekerja, aktivitas sekolah dan aktivitas lainnya adalah nyata.

Tabel 9 Simulasi 1

\begin{tabular}{ccccccccccccc}
\hline $\mathbf{X 5}$ & $\mathbf{X} 7$ & $\mathbf{X 8}$ & $\mathbf{Y}_{\mathbf{0}}$ & $\mathbf{Y}_{\mathbf{1}}$ & $\mathbf{Y}_{\mathbf{2}}$ & $\mathbf{e}^{\mathbf{Y 0}}$ & $\mathbf{e}^{\mathbf{Y}}$ & $\mathbf{e}^{\mathbf{Y}}$ & $\mathbf{e}^{\mathbf{Y} \mathbf{+}}+\mathbf{e}^{\mathbf{Y} \mathbf{+}}+\mathbf{e}^{\mathbf{Y} \mathbf{2}}$ & $\mathbf{P}_{\mathbf{0}}$ & $\mathbf{P}_{\mathbf{1}}$ & $\mathbf{P}_{\mathbf{2}}$ \\
\hline 0 & 0 & 0 & 0 & -4.02 & -3.50 & 1.00 & 0.02 & 0.03 & 1.05 & 0.9540 & 0.0171 & 0.0288 \\
0.25 & 0 & 0 & 0 & -3.28 & -2.88 & 1.00 & 0.04 & 0.06 & 1.09 & 0.9141 & 0.0344 & 0.0515 \\
0.5 & 0 & 0 & 0 & -2.54 & -2.25 & 1.00 & 0.08 & 0.11 & 1.18 & 0.8445 & 0.0667 & 0.0887 \\
0.75 & 0 & 0 & 0 & -1.80 & -1.63 & 1.00 & 0.17 & 0.20 & 1.36 & 0.7344 & 0.1217 & 0.1439 \\
1 & 0 & 0 & 0 & -1.06 & -1.01 & 1.00 & 0.35 & 0.37 & 1.71 & 0.5838 & 0.2029 & 0.2132 \\
1.25 & 0 & 0 & 0 & -0.32 & -0.38 & 1.00 & 0.73 & 0.68 & 2.41 & 0.4150 & 0.3024 & 0.2826 \\
1.5 & 0 & 0 & 0 & 0.42 & 0.24 & 1.00 & 1.53 & 1.27 & 3.80 & 0.2633 & 0.4024 & 0.3343 \\
1.75 & 0 & 0 & 0 & 1.16 & 0.86 & 1.00 & 3.21 & 2.37 & 6.57 & 0.1521 & 0.4876 & 0.3602 \\
2 & 0 & 0 & 0 & 1.91 & 1.49 & 1.00 & 6.72 & 4.42 & 12.14 & 0.0824 & 0.5538 & 0.3638 \\
2.25 & 0 & 0 & 0 & 2.65 & 2.11 & 1.00 & 14.10 & 8.23 & 23.33 & 0.0429 & 0.6042 & 0.3529 \\
2.5 & 0 & 0 & 0 & 3.39 & 2.73 & 1.00 & 29.56 & 15.35 & 45.91 & 0.0218 & 0.6439 & 0.3344 \\
2.75 & 0 & 0 & 0 & 4.13 & 3.35 & 1.00 & 61.99 & 28.63 & 91.62 & 0.0109 & 0.6766 & 0.3124 \\
3 & 0 & 0 & 0 & 4.87 & 3.98 & 1.00 & 130.00 & 53.38 & 184.38 & 0.0054 & 0.7051 & 0.2895 \\
\hline
\end{tabular}

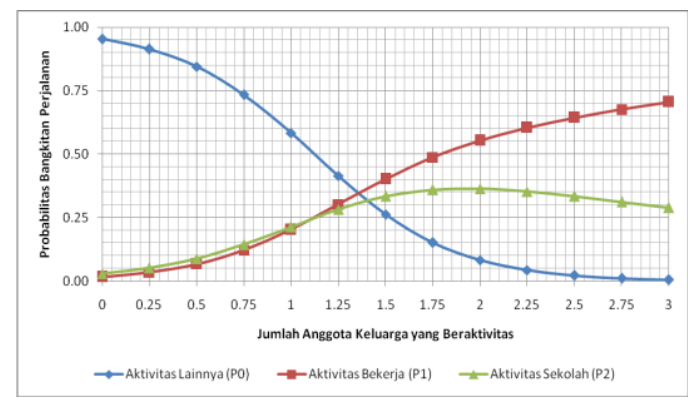

Gambar 1 Probabilitas berdasarkan jumlah anggota keluarga

\section{b. Simulasi 2: Pengaruh jarak tempuh rata-rata saat beraktivitas terhadap probabilitas bangkitan perjalanan.}

Berdasarkan Tabel 10 dan Gambar 2, jika faktor jarak tempuh rata-rata bergerak dari nilai minimum ke maksimum mengakibatkan probabilitas aktivitas bekerja dan sekolah cenderung menurun. Untuk aktivitas bekerja, probabilitasnya mulai dari $1.71 \%$ menjadi $0.05 \%$ dan untuk aktivitas sekolah probabilitasnya mulai dari $2.88 \%$ menjadi $0.05 \%$. Sedangkan untuk aktivitas lainnya, penambahan jarak tempuh rata-rata cenderung menaikkan probabilitasnya yaitu mulai dari $95.40 \%$ menjadi $99.89 \%$.

Perubahan ekstrim jarak tempuh rata-rata (nilai berubah dari 0 ke 4) menurunkan probabilitas untuk aktivitas bekerja sebesar $1.66 \%$ (dari $1.71 \%$ menjadi $0.05 \%$ ), menurunkan probabilitas untuk aktivitas sekolah sebesar $2.83 \%$ (dari $2.88 \%$ menjadi $0.05 \%$ ) dan meningkatkan probabilitas aktivitas lainnya sebesar $4.49 \%$ (dari $95.40 \%$ menjadi 99.89\%). Berdasarkan hasil 
analisis, diketahui bahwa perubahan dugaan peluang sebagai akibat penambahan jarak tempuh rata-rata pada aktivitas bekerja, aktivitas sekolah dan aktivitas lainnya adalah nyata.

Tabel 10 Simulasi 2

\begin{tabular}{ccccccccccccc}
\hline $\mathbf{X 5}$ & $\mathbf{X} 7$ & $\mathbf{X 8}$ & $\mathbf{Y}_{\mathbf{0}}$ & $\mathbf{Y}_{\mathbf{1}}$ & $\mathbf{Y}_{\mathbf{2}}$ & $\mathbf{e}^{\mathbf{Y 0}}$ & $\mathbf{e}^{\mathbf{Y 1}}$ & $\mathbf{e}^{\mathbf{Y} \mathbf{2}}$ & $\mathbf{e}^{\mathbf{Y} \mathbf{+}}+\mathbf{e}^{\mathbf{Y} 1}+\mathbf{e}^{\mathbf{Y} \mathbf{2}}$ & $\mathbf{P}_{\mathbf{0}}$ & $\mathbf{P}_{\mathbf{1}}$ & $\mathbf{P}_{\mathbf{2}}$ \\
\hline 0 & 0 & 0 & 0 & -4.02 & -3.50 & 1.00 & 0.02 & 0.03 & 1.05 & 0.9540 & 0.0171 & 0.0288 \\
0 & 0.25 & 0 & 0 & -4.24 & -3.75 & 1.00 & 0.01 & 0.02 & 1.04 & 0.9635 & 0.0139 & 0.0226 \\
0 & 0.5 & 0 & 0 & -4.46 & -4.00 & 1.00 & 0.01 & 0.02 & 1.03 & 0.9710 & 0.0112 & 0.0177 \\
0 & 0.75 & 0 & 0 & -4.68 & -4.26 & 1.00 & 0.01 & 0.01 & 1.02 & 0.9771 & 0.0091 & 0.0139 \\
0 & 1 & 0 & 0 & -4.90 & -4.51 & 1.00 & 0.01 & 0.01 & 1.02 & 0.9819 & 0.0073 & 0.0108 \\
0 & 1.25 & 0 & 0 & -5.12 & -4.76 & 1.00 & 0.01 & 0.01 & 1.01 & 0.9857 & 0.0059 & 0.0084 \\
0 & 1.5 & 0 & 0 & -5.34 & -5.01 & 1.00 & 0.00 & 0.01 & 1.01 & 0.9887 & 0.0048 & 0.0066 \\
0 & 1.75 & 0 & 0 & -5.56 & -5.27 & 1.00 & 0.00 & 0.01 & 1.01 & 0.9911 & 0.0038 & 0.0051 \\
0 & 2 & 0 & 0 & -5.78 & -5.52 & 1.00 & 0.00 & 0.00 & 1.01 & 0.9929 & 0.0031 & 0.0040 \\
0 & 2.25 & 0 & 0 & -6.00 & -5.77 & 1.00 & 0.00 & 0.00 & 1.01 & 0.9944 & 0.0025 & 0.0031 \\
0 & 2.5 & 0 & 0 & -6.22 & -6.02 & 1.00 & 0.00 & 0.00 & 1.00 & 0.9956 & 0.0020 & 0.0024 \\
0 & 2.75 & 0 & 0 & -6.44 & -6.27 & 1.00 & 0.00 & 0.00 & 1.00 & 0.9965 & 0.0016 & 0.0019 \\
0 & 3 & 0 & 0 & -6.66 & -6.53 & 1.00 & 0.00 & 0.00 & 1.00 & 0.9973 & 0.0013 & 0.0015 \\
0 & 3.25 & 0 & 0 & -6.88 & -6.78 & 1.00 & 0.00 & 0.00 & 1.00 & 0.9978 & 0.0010 & 0.0011 \\
0 & 3.5 & 0 & 0 & -7.10 & -7.03 & 1.00 & 0.00 & 0.00 & 1.00 & 0.9983 & 0.0008 & 0.0009 \\
0 & 3.75 & 0 & 0 & -7.32 & -7.28 & 1.00 & 0.00 & 0.00 & 1.00 & 0.9986 & 0.0007 & 0.0007 \\
0 & 4 & 0 & 0 & -7.53 & -7.54 & 1.00 & 0.00 & 0.00 & 1.00 & 0.9989 & 0.0005 & 0.0005 \\
\hline
\end{tabular}

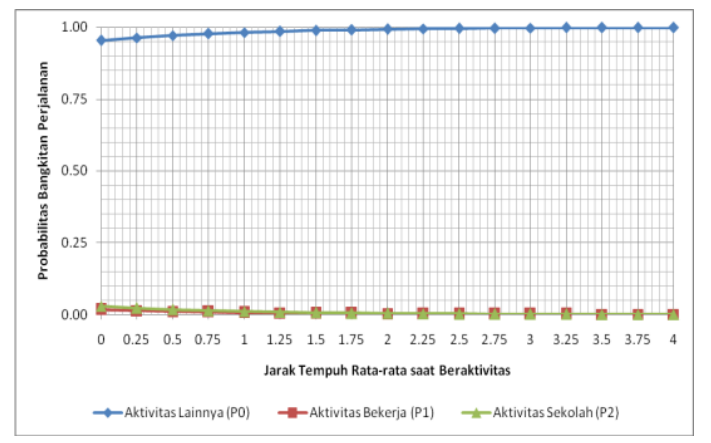

Gambar 2 Probabilitas berdasarkan jarak tempuh rata-rata

\section{c. Simulasi 3: Pengaruh waktu tempuh rata-rata saat beraktivitas terhadap probabilitas bangkitan perjalanan.}

Berdasarkan Tabel 11 dan Gambar 3, jika faktor waktu tempuh rata-rata bergerak dari nilai minimum ke maksimum mengakibatkan probabilitas aktivitas bekerja dan sekolah cenderung meningkat. Untuk aktivitas bekerja, probabilitasnya mulai dari $1.71 \%$ menjadi $44.57 \%$ dan untuk aktivitas sekolah probabilitasnya mulai dari $2.88 \%$ menjadi $36.24 \%$. Sedangkan untuk aktivitas lainnya, penambahan waktu tempuh rata-rata cenderung menurunkan probabilitasnya yaitu mulai dari $95.40 \%$ menjadi $19.19 \%$.

Perubahan ekstrim waktu tempuh rata-rata (nilai berubah dari 0 ke 4) meningkatkan probabilitas untuk aktivitas bekerja sebesar $42.86 \%$ (dari $1.71 \%$ menjadi $44.57 \%$ ), meningkatkan probabilitas untuk aktivitas sekolah sebesar $33.36 \%$ (dari $2.88 \%$ menjadi $36.24 \%$ ) dan menurunkan probabilitas untuk aktivitas lainnya sebesar $76.21 \%$ (dari $95.40 \%$ menjadi $19.19 \%$ ). Berdasarkan hasil analisis data, diketahui bahwa perubahan dugaan peluang sebagai akibat penambahan waktu tempuh rata-rata pada aktivitas bekerja, aktivitas sekolah dan aktivitas lainnya adalah nyata. 
Tabel 11 Simulasi 3

\begin{tabular}{ccccccccccccc}
\hline $\mathbf{X 5}$ & $\mathbf{X} 7$ & $\mathbf{X 8}$ & $\mathbf{Y}_{\mathbf{0}}$ & $\mathbf{Y}_{\mathbf{1}}$ & $\mathbf{Y}_{\mathbf{2}}$ & $\mathbf{e}^{\mathbf{Y} \mathbf{0}}$ & $\mathbf{e}^{\mathbf{Y 1}}$ & $\mathbf{e}^{\mathbf{Y} \mathbf{2}}$ & $\mathbf{e}^{\mathbf{Y} \mathbf{}}+\mathbf{e}^{\mathbf{Y 1}}+\mathbf{e}^{\mathbf{Y} 2}$ & $\mathbf{P}_{\mathbf{0}}$ & $\mathbf{P}_{\mathbf{1}}$ \\
\hline 0 & 0 & 0 & 0 & -4.02 & -3.50 & 1.00 & 0.02 & 0.03 & 1.05 & 0.9540 & 0.0171 & 0.0288 \\
0 & 0 & 0.25 & 0 & -3.72 & -3.24 & 1.00 & 0.02 & 0.04 & 1.06 & 0.9403 & 0.0229 & 0.0368 \\
0 & 0 & 0.5 & 0 & -3.41 & -2.98 & 1.00 & 0.03 & 0.05 & 1.08 & 0.9228 & 0.0305 & 0.0467 \\
0 & 0 & 0.75 & 0 & -3.11 & -2.72 & 1.00 & 0.04 & 0.07 & 1.11 & 0.9006 & 0.0403 & 0.0591 \\
0 & 0 & 1 & 0 & -2.80 & -2.47 & 1.00 & 0.06 & 0.08 & 1.15 & 0.8730 & 0.0529 & 0.0742 \\
0 & 0 & 1.25 & 0 & -2.50 & -2.21 & 1.00 & 0.08 & 0.11 & 1.19 & 0.8388 & 0.0689 & 0.0923 \\
0 & 0 & 1.5 & 0 & -2.20 & -1.95 & 1.00 & 0.11 & 0.14 & 1.25 & 0.7976 & 0.0887 & 0.1136 \\
0 & 0 & 1.75 & 0 & -1.89 & -1.69 & 1.00 & 0.15 & 0.18 & 1.34 & 0.7489 & 0.1129 & 0.1381 \\
0 & 0 & 2 & 0 & -1.59 & -1.43 & 1.00 & 0.20 & 0.24 & 1.44 & 0.6929 & 0.1416 & 0.1655 \\
0 & 0 & 2.25 & 0 & -1.28 & -1.17 & 1.00 & 0.28 & 0.31 & 1.59 & 0.6305 & 0.1745 & 0.1950 \\
0 & 0 & 2.5 & 0 & -0.98 & -0.91 & 1.00 & 0.38 & 0.40 & 1.78 & 0.5632 & 0.2113 & 0.2256 \\
0 & 0 & 2.75 & 0 & -0.68 & -0.66 & 1.00 & 0.51 & 0.52 & 2.03 & 0.4933 & 0.2508 & 0.2559 \\
0 & 0 & 3 & 0 & -0.37 & -0.40 & 1.00 & 0.69 & 0.67 & 2.36 & 0.4236 & 0.2918 & 0.2845 \\
0 & 0 & 3.25 & 0 & -0.07 & -0.14 & 1.00 & 0.93 & 0.87 & 2.80 & 0.3567 & 0.3330 & 0.3103 \\
0 & 0 & 3.5 & 0 & 0.24 & 0.12 & 1.00 & 1.27 & 1.13 & 3.39 & 0.2949 & 0.3730 & 0.3321 \\
0 & 0 & 3.75 & 0 & 0.54 & 0.38 & 1.00 & 1.71 & 1.46 & 4.17 & 0.2397 & 0.4108 & 0.3495 \\
0 & 0 & 4 & 0 & 0.84 & 0.64 & 1.00 & 2.32 & 1.89 & 5.21 & 0.1919 & 0.4457 & 0.3624 \\
\hline
\end{tabular}

Gambar 3 Probabilitas berdasarkan waktu tempuh rata-rata

\subsection{Estimasi Probabilitas Bangkitan Perjalanan Berdasarkan Aktivitas}

Selanjutnya dilakukan estimasi persentase probabilitas bangkitan perjalanan dalam 48 skenario dari faktor-faktor yang berpengaruh signifikan. Skenario dibuat dalam bentuk matriks bangkitan perjalanan dan hasilnya disajikan dalam Tabel 12. Hasil estimasi probabilitas bangkitan perjalanan kemudian diplot pada diagram Radar berdasarkan aktivitas yang ditampilkan dalam Gambar 4.

Tabel 12 Probabilitas bangkitan perjalanan dalam 48 skenario

\begin{tabular}{|c|c|c|c|c|c|c|c|c|c|c|c|c|}
\hline $\mathrm{X5}$ & $\mathbf{X 7}$ & X8 & $\mathbf{Y}_{0}$ & $\mathbf{Y}_{1}$ & $\mathbf{Y}_{2}$ & $\mathrm{e}^{\mathrm{Y} 0}$ & $\mathrm{e}^{\mathrm{Y} 1}$ & $\mathrm{e}^{\mathrm{Y} 2}$ & $\mathrm{e}^{\mathrm{Y} 0}+\mathrm{e}^{\mathrm{Y} 1}+\mathrm{e}^{\mathrm{Y} 2}$ & $\mathbf{P}_{0}$ & $\mathbf{P}_{1}$ & $\mathbf{P}_{2}$ \\
\hline 1 & 1 & 1 & 0 & -0.72 & -0.98 & 1.00 & 0.49 & 0.37 & 1.86 & 0.5373 & 0.2615 & 0.2012 \\
\hline 1 & 1 & 2 & 0 & 0.50 & 0.05 & 1.00 & 1.64 & 1.05 & 3.69 & 0.2707 & 0.4442 & 0.2850 \\
\hline 1 & 1 & 3 & 0 & 1.71 & 1.09 & 1.00 & 5.53 & 2.96 & 9.49 & 0.1053 & 0.5828 & 0.3119 \\
\hline 1 & 1 & 4 & 0 & 2.93 & 2.12 & 1.00 & 18.65 & 8.32 & 27.98 & 0.0357 & 0.6667 & 0.2975 \\
\hline 1 & 2 & 1 & 0 & -1.60 & -1.99 & 1.00 & 0.20 & 0.14 & 1.34 & 0.7471 & 0.1509 & 0.1020 \\
\hline 1 & 2 & 2 & 0 & -0.38 & -0.96 & 1.00 & 0.68 & 0.38 & 2.07 & 0.4842 & 0.3299 & 0.1859 \\
\hline 1 & 2 & 3 & 0 & 0.83 & 0.08 & 1.00 & 2.30 & 1.08 & 4.38 & 0.2285 & 0.5249 & 0.2466 \\
\hline 1 & 2 & 4 & 0 & 2.05 & 1.11 & 1.00 & 7.75 & 3.03 & 11.78 & 0.0849 & 0.6575 & 0.2576 \\
\hline 1 & 3 & 1 & 0 & -2.48 & -3.00 & 1.00 & 0.08 & 0.05 & 1.13 & 0.8821 & 0.0740 & 0.0439 \\
\hline 1 & 3 & 2 & 0 & -1.26 & -1.97 & 1.00 & 0.28 & 0.14 & 1.42 & 0.7028 & 0.1988 & 0.0984 \\
\hline 1 & 3 & 3 & 0 & -0.05 & -0.93 & 1.00 & 0.95 & 0.39 & 2.35 & 0.4260 & 0.4063 & 0.1676 \\
\hline 1 & 3 & 4 & 0 & 1.17 & 0.10 & 1.00 & 3.22 & 1.11 & 5.32 & 0.1879 & 0.6042 & 0.2079 \\
\hline 1 & 4 & 1 & 0 & -3.36 & -4.01 & 1.00 & 0.03 & 0.02 & 1.05 & 0.9497 & 0.0331 & 0.0172 \\
\hline 1 & 4 & 2 & 0 & -2.14 & -2.98 & 1.00 & 0.12 & 0.05 & 1.17 & 0.8558 & 0.1005 & 0.0437 \\
\hline 1 & 4 & 3 & 0 & -0.93 & -1.94 & 1.00 & 0.40 & 0.14 & 1.54 & 0.6495 & 0.2573 & 0.0932 \\
\hline 1 & 4 & 4 & 0 & 0.29 & -0.91 & 1.00 & 1.34 & 0.40 & 2.74 & 0.3651 & 0.4876 & 0.1473 \\
\hline 2 & 1 & 1 & 0 & 2.24 & 1.51 & 1.00 & 9.41 & 4.53 & 14.94 & 0.0669 & 0.6300 & 0.3030 \\
\hline 2 & 1 & 2 & 0 & 3.46 & 2.54 & 1.00 & 31.73 & 12.73 & 45.46 & 0.0220 & 0.6980 & 0.2800 \\
\hline 2 & 1 & 3 & 0 & 4.67 & 3.58 & 1.00 & 107.00 & 35.79 & 143.79 & 0.0070 & 0.7441 & 0.2489 \\
\hline
\end{tabular}

Probabilitas Bangkitan Perjalanan Berbasis Aktivitas Dari Kawasan Perumahan di Kota Kupang - Oktovianus Edvict Semiun, Egidius Kalogo 


\begin{tabular}{|c|c|c|c|c|c|c|c|c|c|c|c|c|}
\hline 2 & 1 & 4 & 0 & 5.89 & 4.61 & 1.00 & 360.78 & 100.63 & 462.41 & 0.0022 & 0.7802 & 0.2176 \\
\hline 2 & 2 & 1 & 0 & 1.36 & 0.50 & 1.00 & 3.91 & 1.65 & 6.56 & 0.1525 & 0.5959 & 0.2517 \\
\hline 2 & 2 & 2 & 0 & 2.58 & 1.53 & 1.00 & 13.18 & 4.64 & 18.82 & 0.0531 & 0.7002 & 0.2466 \\
\hline 2 & 2 & 3 & 0 & 3.79 & 2.57 & 1.00 & 44.43 & 13.05 & 58.48 & 0.0171 & 0.7598 & 0.2231 \\
\hline 2 & 2 & 4 & 0 & 5.01 & 3.60 & 1.00 & 149.81 & 36.69 & 187.49 & 0.0053 & 0.7990 & 0.1957 \\
\hline 2 & 3 & 1 & 0 & 0.48 & -0.51 & 1.00 & 1.62 & 0.60 & 3.22 & 0.3101 & 0.5032 & 0.1866 \\
\hline 2 & 3 & 2 & 0 & 1.70 & 0.53 & 1.00 & 5.47 & 1.69 & 8.16 & 0.1225 & 0.6702 & 0.2073 \\
\hline 2 & 3 & 3 & 0 & 2.91 & 1.56 & 1.00 & 18.45 & 4.76 & 24.21 & 0.0413 & 0.7621 & 0.1965 \\
\hline 2 & 3 & 4 & 0 & 4.13 & 2.59 & 1.00 & 62.20 & 13.38 & 76.58 & 0.0131 & 0.8123 & 0.1747 \\
\hline 2 & 4 & 1 & 0 & -0.39 & -1.52 & 1.00 & 0.67 & 0.22 & 1.89 & 0.5282 & 0.3559 & 0.1159 \\
\hline 2 & 4 & 2 & 0 & 0.82 & -0.48 & 1.00 & 2.27 & 0.62 & 3.89 & 0.2572 & 0.5842 & 0.1586 \\
\hline 2 & 4 & 3 & 0 & 2.04 & 0.55 & 1.00 & 7.66 & 1.73 & 10.39 & 0.0962 & 0.7369 & 0.1669 \\
\hline 2 & 4 & 4 & 0 & 3.25 & 1.58 & 1.00 & 25.83 & 4.88 & 31.71 & 0.0315 & 0.8146 & 0.1538 \\
\hline 3 & 1 & 1 & 0 & 5.20 & 4.00 & 1.00 & 182.01 & 54.72 & 237.73 & 0.0042 & 0.7656 & 0.2302 \\
\hline 3 & 1 & 2 & 0 & 6.42 & 5.04 & 1.00 & 613.72 & 153.87 & 768.59 & 0.0013 & 0.7985 & 0.2002 \\
\hline 3 & 1 & 3 & 0 & 7.64 & 6.07 & 1.00 & 2069.38 & 432.64 & 2503.02 & 0.0004 & 0.8268 & 0.1728 \\
\hline 3 & 1 & 4 & 0 & 8.85 & 7.10 & 1.00 & 6977.66 & 1216.52 & 8195.18 & 0.0001 & 0.8514 & 0.1484 \\
\hline 3 & 2 & 1 & 0 & 4.33 & 2.99 & 1.00 & 75.58 & 19.95 & 96.53 & 0.0104 & 0.7829 & 0.2067 \\
\hline 3 & 2 & 2 & 0 & 5.54 & 4.03 & 1.00 & 254.83 & 56.10 & 311.93 & 0.0032 & 0.8169 & 0.1798 \\
\hline 3 & 2 & 3 & 0 & 6.76 & 5.06 & 1.00 & 859.26 & 157.74 & 1018.00 & 0.0010 & 0.8441 & 0.1550 \\
\hline 3 & 2 & 4 & 0 & 7.97 & 6.09 & 1.00 & 2897.30 & 443.54 & 3341.84 & 0.0003 & 0.8670 & 0.1327 \\
\hline 3 & 3 & 1 & 0 & 3.45 & 1.98 & 1.00 & 31.38 & 7.27 & 39.66 & 0.0252 & 0.7913 & 0.1834 \\
\hline 3 & 3 & 2 & 0 & 4.66 & 3.02 & 1.00 & 105.81 & 20.45 & 127.27 & 0.0079 & 0.8314 & 0.1607 \\
\hline 3 & 3 & 3 & 0 & 5.88 & 4.05 & 1.00 & 356.79 & 57.51 & 415.30 & 0.0024 & 0.8591 & 0.1385 \\
\hline 3 & 3 & 4 & 0 & 7.09 & 5.09 & 1.00 & 1203.03 & 161.72 & 1365.75 & 0.0007 & 0.8809 & 0.1184 \\
\hline 3 & 4 & 1 & 0 & 2.57 & 0.98 & 1.00 & 13.03 & 2.65 & 16.68 & 0.0599 & 0.7811 & 0.1590 \\
\hline 3 & 4 & 2 & 0 & 3.78 & 2.01 & 1.00 & 43.94 & 7.46 & 52.39 & 0.0191 & 0.8386 & 0.1423 \\
\hline 3 & 4 & 3 & 0 & 5.00 & 3.04 & 1.00 & 148.15 & 20.97 & 170.12 & 0.0059 & 0.8709 & 0.1233 \\
\hline 3 & 4 & 4 & 0 & 6.21 & 4.08 & 1.00 & 499.53 & 58.96 & 559.49 & 0.0018 & 0.8928 & 0.1054 \\
\hline \multicolumn{13}{|c|}{ Rata-rata Probabilitas Bangkitan Perjalanan dari Kawasan Perumahan di Kota Kupang } \\
\hline $\mathbf{X 5}$ & $\mathbf{X} 7$ & $\mathbf{X 8}$ & $\mathbf{Y}_{0}$ & $\mathbf{Y}_{1}$ & $\mathbf{Y}_{2}$ & $\mathrm{e}^{\mathrm{Y0}}$ & $\mathbf{e}^{\mathbf{Y 1}}$ & $\mathbf{e}^{\mathbf{Y 2}}$ & $\mathrm{e}^{\mathrm{Y} 0}+\mathrm{e}^{\mathrm{Y} 1}+\mathrm{e}^{\mathrm{Y} 2}$ & $\mathbf{P}_{\mathbf{0}}$ & $\mathbf{P}_{1}$ & $\mathbf{P}_{2}$ \\
\hline 1.49 & 1.88 & 1.91 & 0 & 1.08 & 0.30 & 1.00 & 2.93 & 1.35 & 5.29 & 0.1890 & 0.5548 & 0.2561 \\
\hline
\end{tabular}

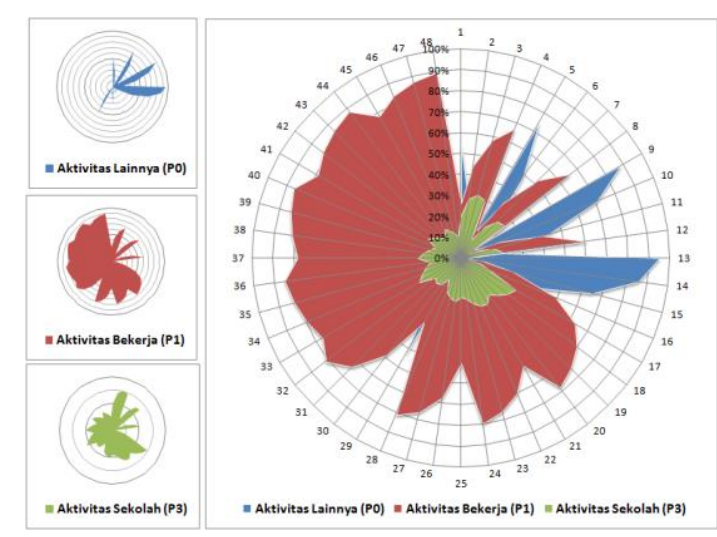

Gambar 4 Probabilitas bangkitan perjalanan dalam 48 skenario

Berdasarkan Tabel 12 dan Gambar 4, probabilitas bangkitan perjalanan yang paling dominan adalah aktivitas mandatory (bekerja dan sekolah) dibandingkan dengan aktivitas nonmandatory (aktivitas lainnya). Untuk memperoleh probabilitas bangkitan perjalanan rata-rata berdasarkan aktivitas bekerja, sekolah dan lainnya dari kawasan perumahan di Kota Kupang dilakukan dengan cara substitusi nilai frekuensi rata-rata dari faktor-faktor yang berpengaruh signifikan ke dalam persamaan MNL sehingga probabilitas bangkitan perjalanan dari kawasan perumahan di kota Kupang diperoleh untuk aktivitas lainnya $18.90 \%$, untuk aktivitas bekerja $55.48 \%$ dan aktivitas sekolah/kuliah sebesar $25.61 \%$ 


\section{Kesimpulan dan Saran}

\subsection{Kesimpulan}

Model regresi multinomial logit bangkitan perjalanan berdasarkan aktivitas dalam penelitian ini telah berhasil dikembangkan dan merupakan model MNL yang valid. Secara serentak, ditemukan bahwa keseluruhan faktor yang merupakan variabel independen mempengaruhi terjadinya bangkitan perjalanan. Namun secara individual, ada tiga faktor yang sangat berpengaruh nyata (sig.) yaitu jumlah anggota keluarga yang beraktivitas, jarak tempuh rata-rata saat beraktivitas dan waktu tempuh rata-rata saat beraktivitas. Apabila ketiga faktor ini mengalami peningkatan aktivitas perjalanan maka probabilitas terjadinya bangkitan perjalanan untuk aktivitas mandatory (bekerja dan sekolah/kuliah) cenderung lebih dominan jika dibandingkan dengan aktivitas nonmandatory (aktivitas lainnya). Berdasarkan frekuensi rata-rata aktivitas perjalanan dari kawasan perumahan di Kota Kupang, diperoleh hasil probabilitas bangkitan perjalanan untuk aktivitas bekerja sebesar $55.48 \%$, untuk aktivitas sekolah/kuliah sebesar $25.61 \%$ dan untuk aktivitas lainnya sebesar $18.90 \%$.

\subsection{Saran}

Penelitian ini menggunakan model statis bangkitan perjalanan sehingga perlu dilakukan penelitian lanjutan dengan mekanisme umpan balik melalui aksesibilitas. Hal ini perlu dilakukan karena seiring meningkatnya permintaan perjalanan di zona tertentu, aksesibilitas cenderung menurun karena kemacetan. Ketika aksesibilitas menurun maka pengembangan lahan dan peningkatan populasi di Kota Kupang cenderung terjadi di masa depan sehingga menahan pertumbuhan permintaan perjalanan.

\section{Ucapan Terima Kasih}

Terima kasih kepada Kementrian Riset dan Teknologi/ Badan Riset dan Inovasi Nasional Deputi Bidang Penguatan Riset dan Pengembangan yang telah memberikan bantuan Dana hibah penelitian dosen pemula periode tahun 2020. Kepada mahasiswa Teknik Sipil Universitas Katolik Widya Mandira yang terlibat dalam mensukseskan penelitan ini.

\section{Daftar Kepustakaan}

Al-Sahili, K., Eisheh, S. A., \& Kobari, F. (2018). Estimation of new development trip impacts through trip generation rates for major land uses in Palestine. Jordan Journal of Civil Engineering, 12(4), 669-682.

Anggraini, R. (2009). Household Activity-Travel Behavior: Implementation of WithinHousehold Interactions. $\mathrm{PhD}$ Thesis. Eindhoven: Technische Universiteit Eindhoven.

Asadi, S. S., Dhulipala, S., Aswin, P., \& Mehta, D. (2016). Modelling of Public Transit Shift Behaviour and Mode Choice in Urban Context : a Case Study of Guntur City. International Journal of Advanced Scientific and Technical Research, 3(6), 52-63. https://rspublication.com/ijst/2016/june16/7.pdf

Badan Pusat Statistik Kota Kupang. (2019). Kota Kupang dalam Angka (2019th ed.). Kupang: Badan Pusat Statistik Kota Kupang. 
Castiglione, J., Bradley, M., \& Gliebe, J. (2014). Activity-Based Travel Demand Models: A Primer. In Activity-Based Travel Demand Models: A Primer (SHRP 2 Rep). Transportation Research Board. https://doi.org/10.17226/22357

Goel, S., Singh, J. B., \& Sinha, A. K. (2012). Trip Distribution Model for Delhi Urban Area Using Genetic Algorithm. International Journal of Computer Engineering Science, 2(3), 1-8.

Hedau, A. L., \& Sanghai, S. S. (2014). Development of Trip Generation Model Using Activity Based Approach. International Journal of Civil, Structural, Environmental and Infrastructure Engineering, 4(3), 61-78. http://www.tjprc.org/viewarchives.php?year $=2014 \&$ jtype $=2 \& \mathrm{id}=26 \&$ details $=$ archives

Hu, S. (2010). Modelling Trip Generation/Trip Accessibility Using Logit Models. Phd Thesis. Edinburgh: Edinburgh Napier University.

Miskeen, M. a. A. Bin, Alhodairi, A. M., \& Rahmat, R. A. A. B. O. K. (2013). Behavior Modeling of Intercity Travel Mode Choice for Business Trips in Libya : A Binary Logit Model of Car and Airplane. Journal of Applied Sciences Research, 9(5), 3271-3280.

Mohan Rao, A., \& Ramachandra Rao, K. (2012). MEASURING URBAN TRAFFIC CONGESTION - A REVIEW. International Journal for Traffic and Transport Engineering. https://doi.org/10.7708/ijtte.2012.2(4).01

Parikh, M. S., \& Varia, H. R. (2016). DEVELOPING SHOPPING TRIP GENERATION MODEL IN RESIDENTIAL AREA OF AHMEDABAD CITY - A CASE STUDY OF GURUKUL AREA. International Journal of Advance Engineering and Research Development, 4(2), 574-584. https://doi.org/10.21090/ijaerd.030433

Patel Bhargavibahen Vinodbhai, D. K. Kadiya, \& Dr. H. R. Varia. (2017). Developing Industrial Trip Generation Model for Himatnagar Industrial Area. International Journal of Engineering Research And, 6(4), 768-775. https://doi.org/10.17577/ijertv6is040670

Patel, H. T., \& Patel, P. V. R. (2015). A Review on Trip Generation Modelling phase of sequential travel demand analysis. International Journal for Scientific Research \& Development, 3(3), 2682-2685.

Sai Simha Gorji, H. V. (2017). Modelling Trip Generation for Urban \& Suburban Areas : A Comparative Case Modelling Trip Generation for Urban \& Suburban Areas : A Comparative Case Study. Imperial Journal of Interdisciplinary Research, 3(5), 446-461.

Semiun, O. E. (2015). Kajian Kinerja Pelayanan Dan Tarif Angkutan Kota Berbasis Atp Dan Wtp Di Kota Kupang. Magister Thesis. Malang: Universitas Brawijaya. https://doi.org/TES/388.049/SEM/k/2015/041501276

Semiun, O. E. (2018). Pengaruh Kualitas Pelayanan Angkutan Kota Terhadap Kepuasan dan Loyalitas Penumpang di Kota Kupang. Rekayasa Sipil, 12(1), 39-49. https://doi.org/10.21776/ub.rekayasasipil/2018.012.01.6

Semiun, O. E. (2019). Pengembangan Pemodelan Multinomial Logit untuk Menentukan Probabilitas Kepemilikan Sepeda Motor di Kota Kupang. TEKNIK, 4O(3), 184. https://doi.org/10.14710/teknik.v40i3.23072

Sreerag, S. R., Sachdeva, S. N., \& Shameem, S. S. (2016). Mode Choice Modelling for Work Trips in Thiruvanathapuham City. Journal of Basic and Applied Engineering Research, 3(4), 381-384. http://www.krishisanskriti.org/Publication.html

Yang, S., Deng, W., Deng, Q., \& Fu, P. (2016). The research on prediction models for urban family member trip generation. KSCE Journal of Civil Engineering. https://doi.org/10.1007/s12205-016-0806-9

Copyright (c) Oktovianus Edvict Semiun

Probabilitas Bangkitan Perjalanan Berbasis Aktivitas Dari Kawasan Perumahan di Kota Kupang - Oktovianus Edvict Semiun, Egidius Kalogo 